\title{
Fatores críticos para a produção de agregado reciclado em usinas de reciclagem de RCC da região nordeste do Brasil
}

\author{
Critical factors in the production of recycled aggregate in \\ CDW recycling plants in Brazil's Northeast region
}

\section{Adriana Virgínia Santana Melo \\ Emerson de Andrade Marques Ferreira \\ Dayana Bastos Costa}

\section{Resumo}

$\Delta$

s usinas de reciclagem de resíduos da construção civil (RCC) no Brasil produzem agregado reciclado com alta variabilidade mineral e baixa empregabilidade. Suas atividades dependem da construção civil e das diretrizes para produção do agregado reciclado, com foco na substituição ao agregado natural. Este trabalho identifica fatores críticos para a produção de agregado reciclado em usinas de reciclagem de RCC por meio da avaliação das usinas da região Nordeste do Brasil, conforme a norma NBR 15114 (ABNT, 2004b). A pesquisa foi dividida em três etapas. Na primeira, foi estabelecida a fundamentação teórica do estudo. Na segunda fase, foram realizadas visitas às usinas para entrevistas, levantamento fotográfico e observação visual. $\mathrm{Na}$ última, os dados coletados foram analisados à luz das diretrizes brasileiras para produção de agregado reciclado. Como resultado, identificou-se que as usinas visitadas sofrem interferências negativas na produção decorrente da gestão dos resíduos da construção civil. Observou-se, ainda, que as usinas avaliadas apresentaram não conformidades em relação aos requisitos da NBR 15114. A contribuição principal deste trabalho é a identificação de fatores críticos e proposições para a produção do agregado reciclado com pureza mineral e maior empregabilidade.

Palavras-chave: Resíduo da construção civil. Usina de reciclagem de RCC. Gestão de resíduos.

Adriana Virgínia Santana Melo Instituto Federal de Sergipe Aracaju - SE - Brasil

Emerson de Andrade Marques

Ferreira

Universidade Federal da Bahia Salvador - BA - Brasil

Dayana Bastos Costa Universidade Federal da Bahia Salvador - BA - Brasil

Recebido em 30/05/10/13

Aceito em 23/07/13

\begin{abstract}
Recycling plants of Construction and Demolition Waste (CDW) in Brazil produce recycled aggregate with a high mineral variability and low usability. Their activities depend on the building industry and on guidelines to produce recycled aggregate, which are focused on replacing natural aggregate. This study identifies critical factors in the production of recycled aggregate at CDW recycling plants. That has been done through the evaluation of recycling plants in the Northeast of Brazil, according to NBR 15114 (ABNT, 2004b). The study was divided into three phases. In the first phase, the theoretical foundation of the study was established. In the second one, a number of plants were visited for interviews, photographs, and direct observation. In the final phase, data were analyzed according to the Brazilian guidelines for the production of recycled aggregate. There were evidences that the production processes in those plants were negatively influenced by the current waste management practices of the construction industry.

Moreover, all plants had non-compliances with requirements of the NBR 15114.

The main contribution of this paper is the identification of the critical factors and offering propositions for the production of recycled aggregate with mineral purity and improved usability.
\end{abstract}

Keywords: Waste construction and demolition. CDW recycling plants. Waste management. 


\section{Introdução}

A utilização dos resíduos da construção civil (RCC) como matéria-prima para produção de agregados reciclados reemprega componentes mineralógicos, auxilia no uso dos recursos naturais e provoca readaptação humana às necessidades de vivência na biota. As áreas destinadas à produção do agregado reciclado são identificadas como usinas de reciclagem de RCC e devem ser reconhecidas como mecanismos de redução do desperdício de matéria-prima mineral reempregável na construção civil (MELO, 2011).

As usinas de reciclagem de RCC são definidas como a área industrial destinada e equipada onde se processa a transformação de RCC, classe A, em dois produtos finais distintos e conceituados pela NBR 15112 (ABNT, 2004a) na forma de agregado de resíduo de concreto (ARC) e de agregado de resíduo misto (ARM).

A qualidade do agregado reciclado, por sua vez, depende de fatores externos e internos às usinas de reciclagem de RCC. Entre os fatores externos estão a técnica de esmagamento do britador, a uniformidade mineral apresentada pelo RCC e a armazenagem do RCC em canteiro de obra. Como fatores internos têm-se as etapas de projeto para implantação das usinas, o tipo de beneficiamento previsto e as linhas de produtos reciclados a comercializar (WASTE..., 2005).

$\mathrm{O}$ processo produtivo, determinado durante $\mathrm{O}$ projeto das usinas, interfere nos requisitos técnicos do agregado reciclado tanto quanto a ausência de diretrizes que balizem o desempenho do agregado reciclado. As usinas fixas, por exemplo, detêm o controle das etapas internas do processo de beneficiamento, se comparadas às unidades móveis (HENDRIKS, 2004; CAR et al., 2008). O maior controle dos requisitos técnicos permite empregabilidade do agregado reciclado em concretos estruturais (WASTE..., 2005).

$\mathrm{Na}$ Europa, as plantas fixas empregam mais de um tipo de britador, e o RCC produzido deve garantir a viabilidade econômica do empreendimento em relação ao custo final do agregado reciclado (LOPÉZ, 2010).

No Brasil, por sua vez, as usinas de reciclagem de RCC são tidas como local para direcionamento e destinação do RCC gerado (NUNES, 2004). A produção do agregado reciclado brasileiro está dissociada das relações de viabilidade econômica ou requisitos técnicos. Em Belo Horizonte, as usinas entraram em operação após o previsto, e a capacidade ociosa está próxima de $40 \%$, fato atribuído ao incômodo provocado na vizinhança (ALMEIDA; CHAVES, 2002). O produto dessas usinas é utilizado pela prefeitura em obras de manutenção, de pavimentação e infraestrutura. No Rio de Janeiro persiste a carência da regulamentação municipal para incentivos à implantação das usinas. Em Salvador, o programa de gestão diferenciada de entulho iniciado em 1998 prevê a implantação de usinas de reciclagem de RCC, que não possuem prazo para início das atividades.

As usinas de reciclagem das regiões Sul, Sudeste e Centro-Oeste foram estudadas por Nunes (2004). A análise teve por base a produção das unidades de Piracicaba, Vinhedo, Guarulhos, Ribeirão Pires, São José do Rio Preto, Belo Horizonte (Estoril e Pampulha), Londrina, Brasília (aterro/jóquei) e Macaé. Na ocasião, exceto as usinas de Belo Horizonte e Vinhedo, todas as outras possuíam como único cliente a própria prefeitura. De modo semelhante, às usinas de Ribeirão Preto e São José dos Campos também produzem agregado reciclado somente para o setor público (CUNHA, 2007).

Nota-se nessas iniciativas que agregado reciclado é absorvido pelo setor público para uso em pavimentação. Nesse caso, os requisitos técnicos para empregabilidade independem do controle de qualidade rigoroso (MELO, 2011).

No período anterior à publicação da NBR 15114 (ABNT, 2004b) foram implantadas no Brasil 18 usinas de reciclagem. A Usina de Reciclagem de Fortaleza (USIFORT) é uma das três usinas privadas dessa época, sendo também a quinta mais antiga em operação no país e a primeira unidade de reciclagem de RCC da região Nordeste (MIRANDA; ÂNGULO; CARELI, 2009). Entre 2004 e 2008 o número de usinas no Brasil cresceu $161 \%$. Nessa fase o número de unidades da região Nordeste aumentou $300 \%$, e a capacidade de produção de $50 \mathrm{t} / \mathrm{h}$ passou para $140 \mathrm{t} / \mathrm{h}$ de agregado reciclado (MIRANDA; ÂNGULO; CARELI, 2009). Assim como outras usinas do país, o principal cliente é o setor público. Em 2013, inicia-se a fase de teste da quinta usina do Nordeste, situada em Aracaju.

Entre as 47 usinas implantadas no Brasil até 2009, inexiste controle da qualidade dos produtos fornecidos nelas, e 11 dessas usinas estão desativadas ou paralisadas (MIRANDA; ÂNGULO; CARELI, 2009). A capacidade de produção, em $\mathrm{t} / \mathrm{h}$, dessas usinas sugere que as concepções utilizadas foram insatisfatórias para a continuidade da atividade produtiva.

Os estudos de viabilidade econômica de Jadoviski (2005) sobre as usinas da região Sudeste afirmam que o custo de reciclagem reduz-se com o aumento 
da capacidade de produção. Para Miranda, Ângulo e Carelli (2009), as usinas de pequeno porte podem ser viáveis se incorporarem valor ao produto.

Diante desse contexto, a produção de agregado reciclado depende do reordenamento das atividades da construção civil e do emprego dos produtos reciclados, com semelhança de exigência entre matéria-prima natural e matéria reciclada. Nesse sentido, as usinas de reciclagem brasileiras devem atender às necessidades da produção com foco no desempenho do produto reciclado.

O presente trabalho visa identificar fatores críticos para a produção de agregado reciclado em usinas por meio da avaliação das usinas de reciclagem de RCC da região Nordeste do Brasil em operação durante o ano de 2010. Na avaliação são usados os parâmetros da NBR 15114 (ABNT, 2004b) quanto às diretrizes de projeto, implantação e operação das áreas de reciclagem de RCC.

$\mathrm{Na}$ época da escolha das usinas de reciclagem, as quatro unidades em operação na região Nordeste apresentaram pouca referência literária em relação às existentes nas regiões Sul e Sudeste do país. Assim, as usinas do Nordeste foram escolhidas por pertencer a mesma região geográfica, apesar de relativa heterogeneidade das demandas urbanas dos municípios-sede. As dimensões continentais da região suscitaram investigações sobre a terminologia do agregado reciclado, as particularidades do RCC recebido nas usinas, as relações entre capacidade de produção e população, bem como as possíveis diferenças operacionais entre as usinas avaliadas.

O número de usinas a avaliar na região Nordeste em relação ao universo do país, contribuiu para que se pudesse abordar a totalidade dos itens da norma NBR 15114 (ABNT, 2004b), bem como avaliar o emprego das boas práticas selecionadas na revisão da literatura.

\section{Parâmetros de projeto, implantação e operação para usinas de reciclagem de RCC}

\section{Requisitos de projeto e implantação}

Países como Japão, Holanda e Espanha apresentam avanços satisfatórios na reciclagem do RCC. Parte desse avanço está associada à escassez das jazidas e aos custos imputados ao gerador quando da disposição final do RCC (LANZELLOTTI; TOREM; LUZ, 2004).

$\mathrm{Na}$ Europa, as usinas fixas possuem área para recepção do $\mathrm{RC}$, e o acesso a elas obedece a: apresentação de licença do Gerenciamento do Resíduo da Construção Civil (GRCC) ou registro da isenção do licenciamento; expresso reconhecimento aos tipos de resíduos aceitos; e submissão aos procedimentos da área de recepção da usina (WASTE..., 2005). Nessas usinas, a conferência do RCC na recepção é documental e visual, e sua constatação ocorre com a derrubada em área adjacente. Quando a contaminação for superior à aceitável, o lote é rejeitado. Uma nova verificação de contaminação ocorre antes da armazenagem, conforme a Figura 1 (WASTE..., 2005).

Além disso, o produto a gerar e a quantidade a produzir são vistos como elementos fundamentais na análise para implantação das usinas (MUTHER, 1978). A inspeção rigorosa do RCC conduz à redução da contaminação da matéria-prima, ao mesmo tempo em que favorece outras etapas produtivas.

Figura 1 - Método de controle em usinas na Europa

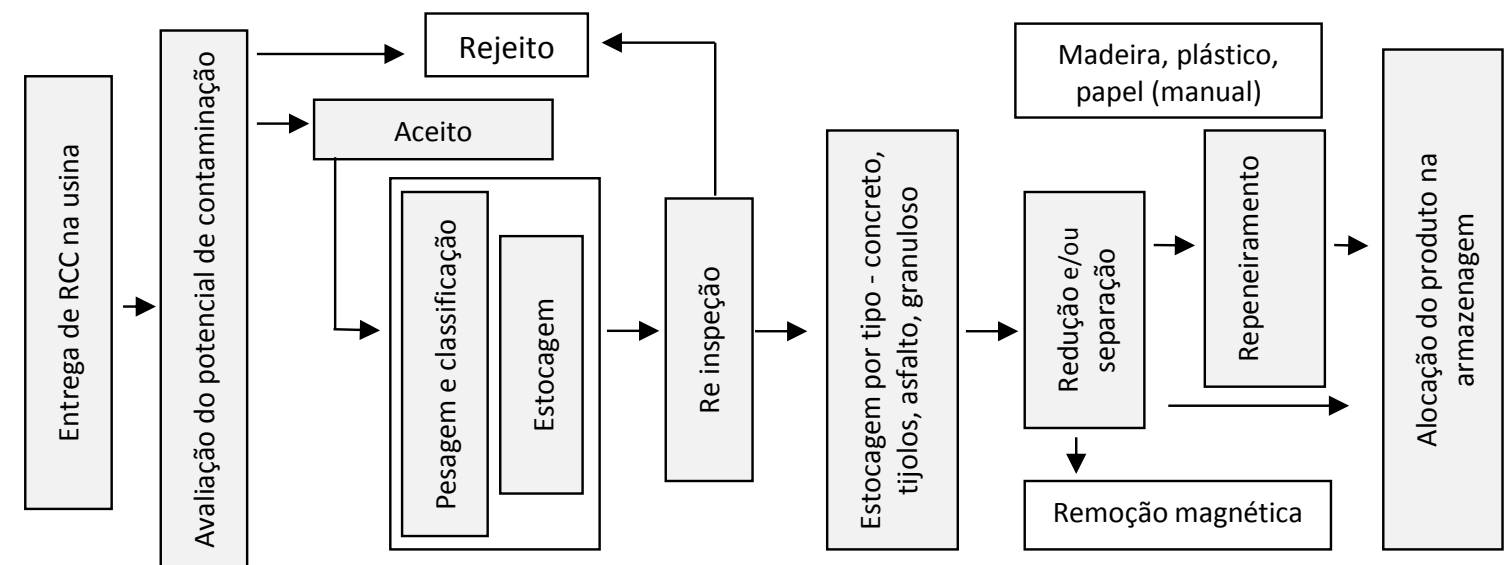

Fonte: adaptado de Waste \& Resources Action Progamme (2005). 
No Brasil, os parâmetros de projeto, implantação e operação das plantas fixas ou semifixas estão descritos na NBR 15114 (ABNT, 2004b) e limitam-se à atividade de redução, sem correlação com outras diretrizes para reúso e reciclagem do RCC, a exemplo da redução das interferências externas e internas às usinas.

Entretanto, outros estudos apontam que o projeto, a implantação e a operação das usinas de reciclagem de RCC devem ter por foco a redução das inteferências negativas na produção do agregado reciclado. Moreira (2001) aponta a localização do empreendimento, o leiaute de beneficiamento, os tipos de equipamento a serem utilizados, o fluxo interno de insumos e resíduos gerados como interferências internas à produção. As interferências externas referem-se à distância de transporte, à disponibilidade dos insumos, aos requisitos do produto (MOREIRA, 2001; MANZINI; VEZZOLI, 2008).

O local de instalação de uma usina de reciclagem de RCC é uma decisão estratégica e faz parte do processo de planejamento, independentemente do agente financiador. $\mathrm{Na}$ iniciativa privada, a escolha pode levar a requisitos de maior rentabilidade com menor custo; já no setor público, o caráter social ou o crescimento regional podem ser determinantes (MOREIRA, 2001).

Para Moreira (2001), o relevo, a facilidade de acesso, a ausência de corpos hídricos, a distância de transporte da matéria-prima e do produto são fatores a serem analisados de forma a beneficiar a produção.

Duarte e Lima (2007) entendem que as diretrizes de implantação das usinas de reciclagem de RCC dizem respeito ao volume de geração do RCC a reciclar, ao tipo de agregado reciclado produzido e à aplicação a que se destina.

\section{Requisitos de operação das usinas}

A escolha do tipo de planta e dos equipamentos adequados aos requisitos técnicos do agregado reciclado requer condições operacionais $\mathrm{e}$ produtivas determinadas durante o projeto dos empreendimentos. As diretrizes para produção do agregado reciclado conduzem a terminologia, a tipologia do RCC, a requisitos técnicos e ensaios de caracterização (BALÁZS; KAUSAY; SIMON, 2008).

No Japão a produção de agregado reciclado graúdo é destinada à construção civil. Para tanto, as diretrizes estabelecem as condições de reciclagem e demolição, bem como a padronização para uso do agregado reciclado (KAWANO, 2003).
Ainda no que se refere ao Japão, Shima et al. (2005) afirmam que o método de aquecimento e atrito (Heating and Rubbing Method - $\mathrm{HRM}^{1}$ ) utilizado nas usinas tem resultado em um agregado reciclado de concreto demolido com alta qualidade, homogeneidade mineral e redução dos finos.

A inserção de equipamentos para prébeneficiamento e eliminação de impurezas do RCC aponta para a redução das extrações de agregados naturais. Para Ângulo et al. (2009), existe uma grande variedade de técnicas que melhoram a qualidade do agregado reciclado.

\section{Requisitos da matéria-prima, do produto e dos resíduos gerados}

A produção do agregado reciclado visando substituir os agregados naturais deve ter aplicação imediata, não oferecendo riscos e respeitando aspectos sociais de aceitação e conformidade à norma. As qualidades físicas necessárias ao agregado reciclado de concreto são resistência à compressão, durabilidade, absorção de água, trabalhabilidade e um bom controle de qualidade para redução da variabilidade (KIBERT, 1994; KASAI, 1994).

Nesse sentido, a Holanda e a Dinamarca determinam igualdade de condições e emprego para os materiais de construção fabricados com materiais naturais e reciclados (BREWER; MOONEY, 2008). No Japão, o agregado reciclado deve ser reinserido na cadeia da construção civil de origem (YOSHIDA, 2007).

O controle tecnológico do produto reciclado favorece a comercialização e consolida as diretrizes para aproveitamento. Hendriks (2004) afirma que são boas as possibilidades de cuidados fora das usinas para melhoria do produto final, resultando em aplicações nobres para o agregado reciclado.

A NBR 15116 (ABNT, 2004c) prevê o controle de qualidade do agregado reciclado com frequência mínima por lotes equivalentes à produção mensal ou volume máximo de $1.500 \mathrm{~m}^{3}$, o que ocorrer primeiro. Além disso, deve ser realizado por tipificação (ARC, ARM) do resíduo classe A e graduação granulométrica produzida.

\section{Método de pesquisa}

A presente pesquisa adotou o levantamento de dados qualitativos como estratégia para a avaliação das usinas, utilizando como fonte de evidência a

\footnotetext{
${ }^{1}$ Usina em que o RCC se aquece a $300^{\circ} \mathrm{C}$ e elimina finos por lavagem e ventilação (SHIMA et al., 2005).
} 
observação direta, a pesquisa documental in loco, o levantamento fotográfico e a entrevista.

A diversidade das evidências construiu o cenário de cada usina, bem como permitiu estabelecer os pontos comuns, as discrepâncias e os fatores críticos que interferem na produção do agregado reciclado em relação aos parâmetros da NBR 15114 (ABNT, 2004b).

A Figura 2 apresenta o delineamento da pesquisa, composta do referencial teórico que definiu os critérios para coleta e análise dos dados, o estudo de caso e a elaboração das diretrizes para a produção do agregado reciclado nas usinas de reciclagem de RCC.

O levantamento de dados foi subdividido em quatro etapas principais:

(a) a seleção das usinas de reciclagem; (b) a elaboração dos instrumentos de coleta de dados; e

(c) a coleta de dados; e a análise final dos dados.

O Quadro 1 contém a relação das usinas visitadas, sua razão social, capacidade de produção e natureza do agente financiador. $\mathrm{Na}$ avaliação das usinas, a identificação foi feita segundo a sequência alfabética "A", "B", "C" e "D", determinada previamente por sorteio aleatório.

$\mathrm{Na}$ elaboração do questionário foi definido um conjunto de constructos baseados nos requisitos da NBR 15114 (ABNT, 2004b) sobre projeto, implantação, operação, matéria-prima, produto e resíduos. O objetivo foi evidenciar as diretrizes utilizadas, bem como as interferências externas e internas à produção.

Figura 2 - Delineamento da pesquisa

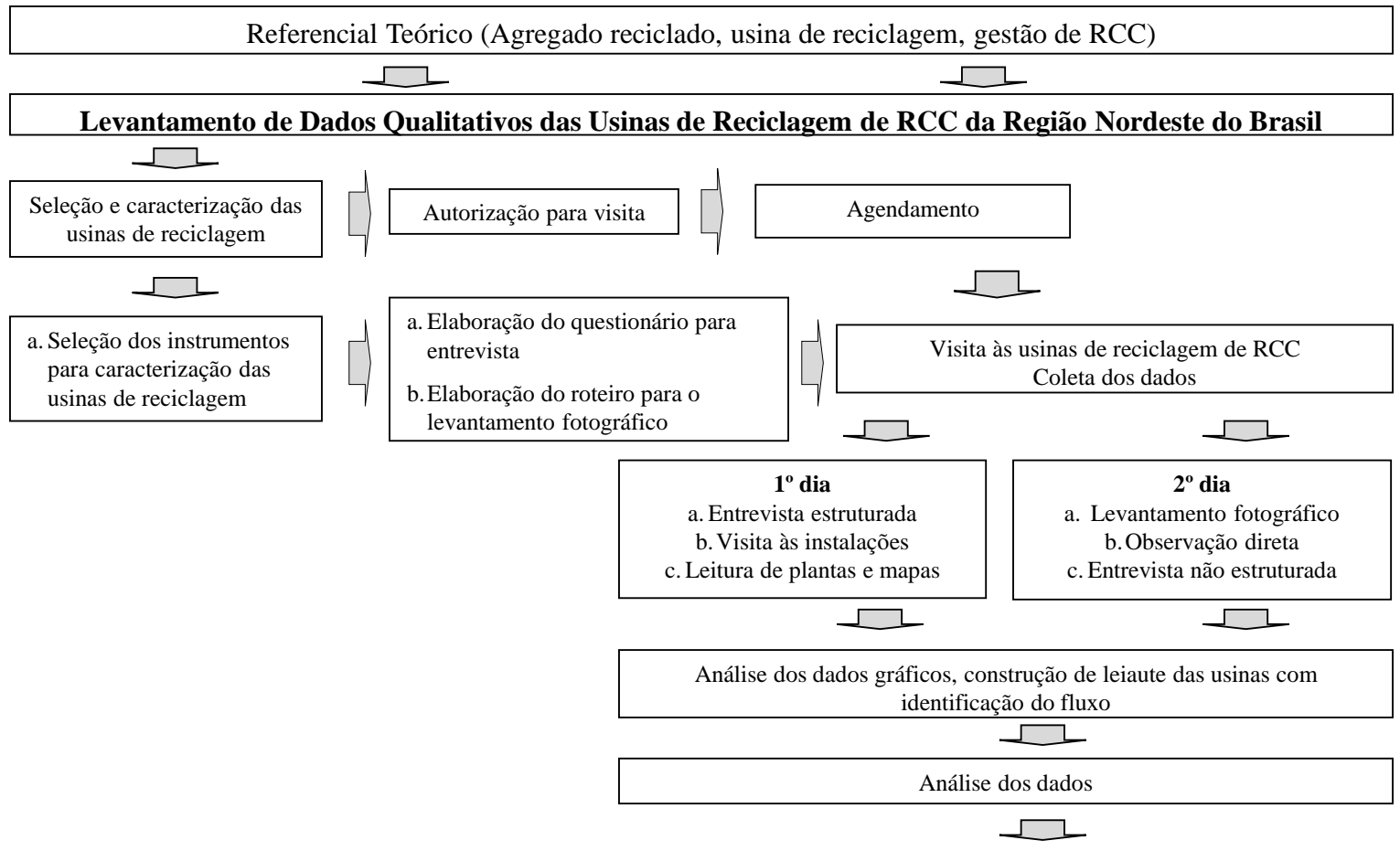

Fatores Críticos e Diretrizes para a Produção de Agregado Reciclado em Usinas de Reciclagem de RCC

Quadro 1 - Relação das usinas de reciclagem de RCC da região Nordeste do Brasil

\begin{tabular}{|c|c|c|c|c|}
\hline Cidade & Designação & $\begin{array}{c}\text { Ano de } \\
\text { Implantação }\end{array}$ & $\begin{array}{c}\text { Capacidade de } \\
\text { Produção (t/h) }\end{array}$ & Natureza \\
\hline Fortaleza & Usina de Reciclagem de Fortaleza - USIFORT & 1997 & 50 & Privada \\
\hline João Pessoa & $\begin{array}{c}\text { Usina de Beneficiamento de Resíduos Sólidos da } \\
\text { Construção e Demolição - USIBEN }\end{array}$ & 2007 & 20 & Pública \\
\hline Petrolina & Usina de Beneficiamento de Entulho - UBE & 2008 & 20 & Pública \\
\hline São Luís & URCD Ilha Grande Comércio, Serviços e Construção & 2008 & 40 & Privada \\
\hline
\end{tabular}


O constructo Projeto e Implantação visou evidenciar o grau de adequação da localização e do terreno ante os requisitos da norma. A investigação buscou determinar quais os critérios para a escolha da localização e do terreno dentro do município, as interferências provocadas no entorno, as reações populares à instalação do empreendimento, as restrições provocadas na produção e como se dá a convivência com as populações impactadas.

A Figura 3 apresenta o delineamento das variáveis analisadas em Projeto e Implantação. Os itens Fatores da Escolha, Acesso Interno, Recepção (local), Triagem (local) estão grifados porque se referem às investigações não citadas na norma brasileira, mas que na revisão literária se mostraram relevantes para a produção do agregado reciclado ou dizem respeito a boas práticas implantadas em usinas.

O constructo Operação buscou os pontos críticos da dinâmica produtiva do agregado reciclado. Para tanto, investigou-se a área de acesso da matériaprima, suas condições de aceitação e rejeição, áreas de movimentação, área para triagem e os equipamentos necessários. Todas as variáveis estavam relacionadas a equipamentos, sequência produtiva, cuidados e restrições. A Figura 4 apresenta as variáveis, e o texto em grifo refere-se a constatações não citadas em norma.

Com relação ao constructo Matéria-prima, Produto e Resíduos, o objetivo foi constatar as interferências produtivas de cada um dos itens. Também foram evidenciados os indicadores do produto reciclado disponibilizado ao mercado, as facilidades e restrições de inserção, as linhas oferecidas, além do manejo e tratamento dos resíduos gerados nas usinas. Nessa etapa foram investigadas quais as formas de controle dos requisitos técnicos, terminologia e indicadores de produtividade das usinas. A Figura 5 detalha a organização do constructo matéria-prima, produto e resíduos.

Para a avaliação das usinas de reciclagem por meio dos requisitos do questionário foram atribuídos os conceitos:

(d) não atende: quando se identificou como diferente, sem correlação de conformidade ao preceituado em norma ou boas práticas, que interfere negativamente na sustentabilidade, atribuindo-se o valor menos um (-1);

(e) atende parcialmente: quando falta parte, elemento ou constituintes que devem existir e são preceituados em norma ou boas práticas.

Entretanto, existe condição favorável à conformidade, apesar do parcial desacordo, atribuindo-se o valor zero (0); e

(f) atende: qualidade ou estado do que é conforme, com correspondência, identidade à forma, preceituado em normas e boas práticas, caso em que se atribuiu valor um (1).

Os critérios avaliados perfazem um total de 28 itens, e a pontuação, por usina, pode oscilar entre 14 pontos (não conformidade em todos os itens) a +14 pontos (conformidade plena).

Figura 3 - Detalhamento da construção dos instrumentos de coleta - projeto e implantação das usinas

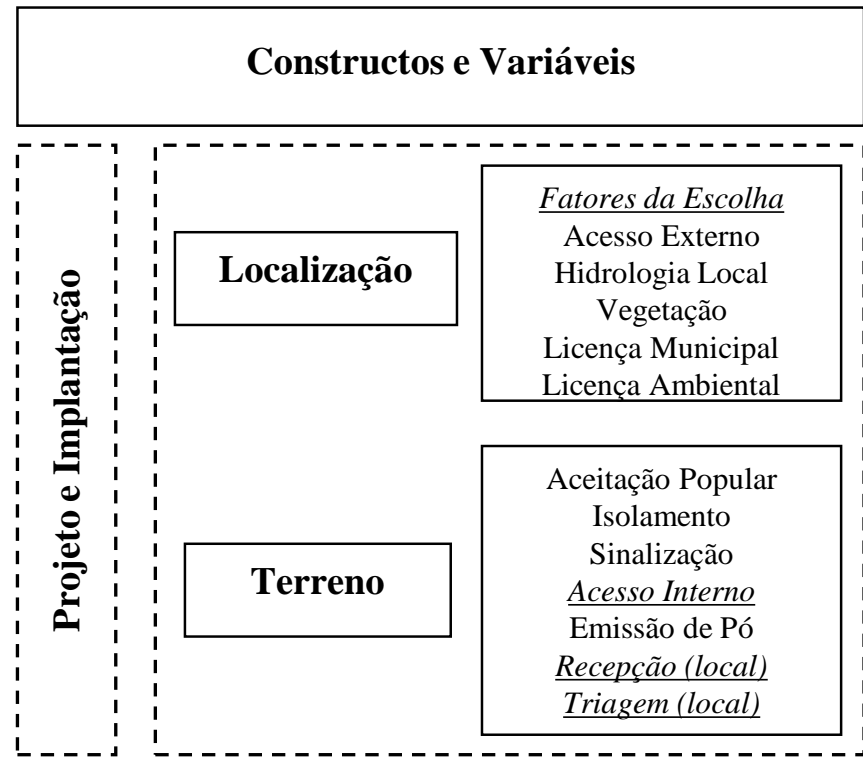

\section{Fontes de Evidências}

Projetos gráficos (arquitetônico, elétrico, localização, mapas eletrônicos), questionários, entrevistas, registros fotográficos. 
Figura 4 - Detalhamento da construção dos instrumentos de coleta - operação das usinas

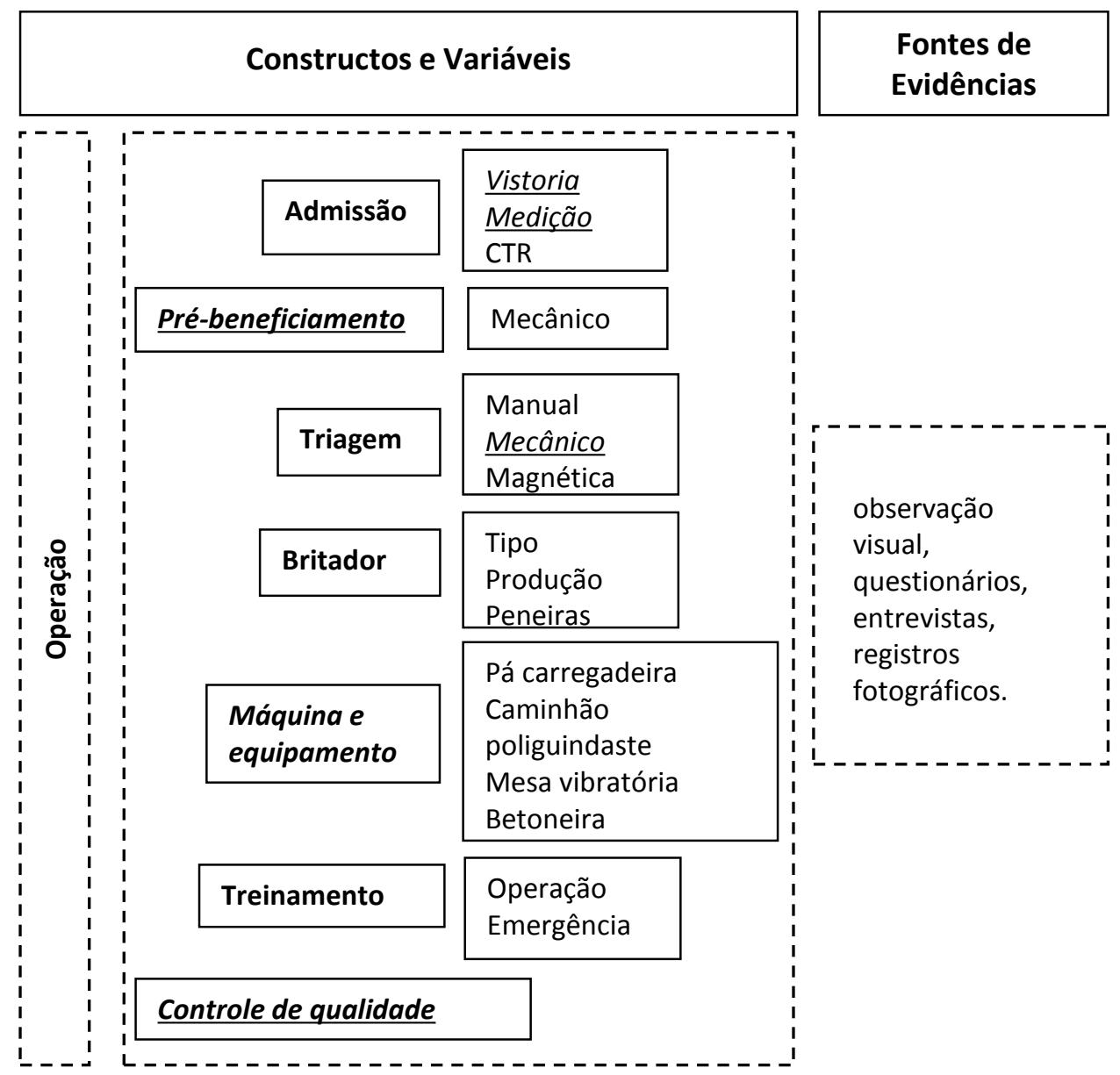

Figura 5 - Detalhamento da construção dos instrumentos de coleta - matéria-prima, produto, resíduos

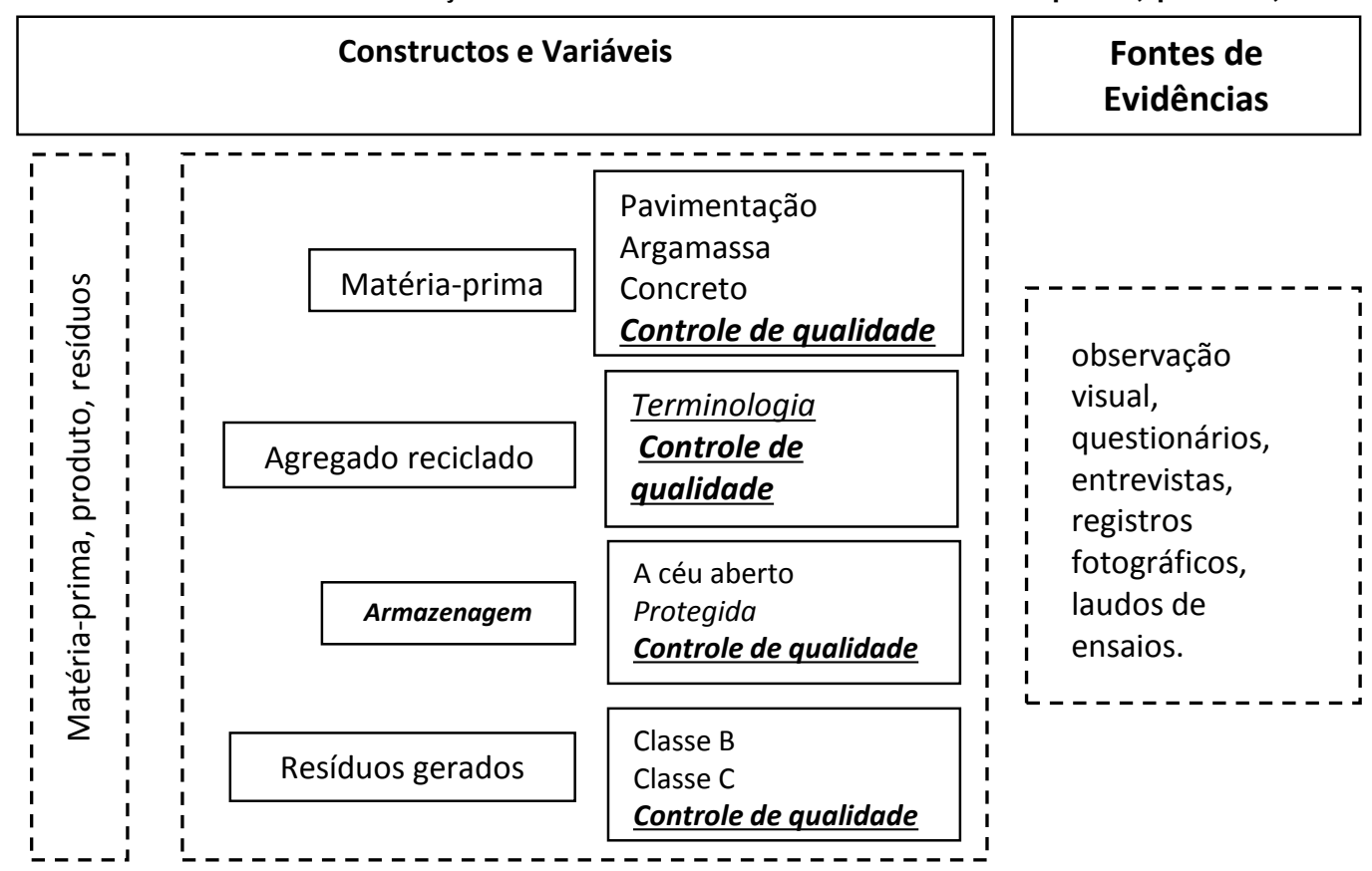




\section{Avaliação das usinas de reciclagem para a produção de agregados reciclados}

A avaliação das usinas foi organizada conforme diretrizes da NBR 15114 (ABNT, 2004b) para as áreas de reciclagem de $\mathrm{RCC}$ - Classe $\mathrm{A}$ e da NBR 15116 (ABNT, 2004c), que estabelece requisitos para o emprego de agregados reciclados.

\section{Projeto e implantação}

No Quadro 2 tem-se o resumo da avaliação das diretrizes relativas à implantação das usinas de reciclagem de RCC estudadas quanto aos aspectos da localização e do terreno.

Das quatro usinas avaliadas, duas são públicas (A e C) e duas são privadas (B e D). Os terrenos destinados às usinas públicas privilegiaram a ocupação de terras próprias. $\mathrm{O}$ objetivo foi respeitar as legislações municipais que determinam o uso e a retomada de terras, evitando novas aquisições. Para a iniciativa privada, os critérios de escolha foram o custo das terras, a disponibilidade para a aquisição, a proximidade de centros urbanos e as áreas de expansão das cidades.

A existência de acessos externos, abertos, adequados ao tráfego intenso de veículos não foi citada como fator desfavorável à escolha da localização. Apesar disso, em três das usinas (B, C e D) esse fator foi apontado como interferência negativa à produção, pois contribui na deterioração das vias e nas emissões de pó e ruído. Como estratégia de boa convivência, as usinas " $\mathrm{B}$ " e " $\mathrm{C}$ " realizam serviços de pavimentação, com equipamentos e agregado reciclado das unidades. A restrição aos horários de operação nessas usinas são outro dispositivo de minimização ao incômodo.

$\mathrm{Na}$ usina "D" as vias de acesso externas apresentam adequação ao deslocamento dos veículos de carga. No que diz respeito aos acessos internos, somente a usina "A" apresentou conformidade.

Quadro 2 - Avaliação das diretrizes - Implantação das usinas

\begin{tabular}{|c|c|c|c|c|c|c|c|c|c|c|c|}
\hline \multirow{2}{*}{\multicolumn{2}{|c|}{$\begin{array}{l}\text { Referências } \\
\text { Normativas }\end{array}$}} & \multirow{3}{*}{$\begin{array}{c}\begin{array}{c}\text { Diretrizes } \\
\text { Observadas }\end{array} \\
\text { Fatores da } \\
\text { Escolha }\end{array}$} & \multirow{3}{*}{ 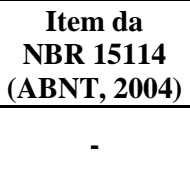 } & \multicolumn{2}{|c|}{ Usina A } & \multicolumn{2}{|c|}{ Usina B } & \multicolumn{2}{|c|}{ Usina $\mathrm{C}$} & \multicolumn{2}{|c|}{ Usina D } \\
\hline & & & & \multirow{2}{*}{$\begin{array}{c}\text { Conceito } \\
\text { Não } \\
\text { atende }\end{array}$} & \multirow{2}{*}{$\frac{\mathbf{V A}^{*}}{-1}$} & \multirow{2}{*}{$\begin{array}{c}\text { Conceito } \\
\text { Não } \\
\text { atende }\end{array}$} & \multirow{2}{*}{$\frac{\mathbf{V A}^{*}}{-1}$} & \multirow{2}{*}{$\begin{array}{c}\text { Conceito } \\
\text { Não } \\
\text { atende }\end{array}$} & \multirow{2}{*}{$\frac{\mathbf{V A}^{*}}{-1}$} & \multirow{2}{*}{$\begin{array}{c}\text { Conceito } \\
\begin{array}{l}\text { Atende } \\
\text { parcial }\end{array}\end{array}$} & \multirow{2}{*}{$\frac{\mathbf{V A}^{*}}{0}$} \\
\hline \multirow{14}{*}{ 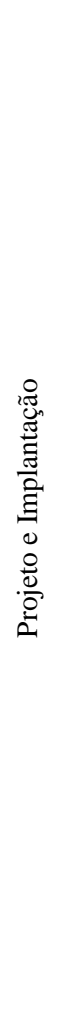 } & \multirow{6}{*}{ ]్త్ర } & & & & & & & & & & \\
\hline & & Acesso Externo & $\begin{array}{c}5.2 .1 \mathrm{c} \\
5.4\end{array}$ & $\begin{array}{c}\text { Não } \\
\text { atende }\end{array}$ & -1 & $\begin{array}{c}\text { Não } \\
\text { atende }\end{array}$ & -1 & $\begin{array}{c}\text { Não } \\
\text { atende }\end{array}$ & -1 & Atende & 1 \\
\hline & & $\begin{array}{l}\text { Hidrologia } \\
\text { Local }\end{array}$ & $\begin{array}{c}5.2 .1 . \mathrm{a} \\
5.6 \\
\end{array}$ & $\begin{array}{c}\text { Não } \\
\text { atende }\end{array}$ & -1 & Atende & 1 & $\begin{array}{c}\text { Não } \\
\text { atende }\end{array}$ & -1 & Atende & 1 \\
\hline & & Vegetação & 5.2.1.b & $\begin{array}{c}\text { Não } \\
\text { atende }\end{array}$ & -1 & $\begin{array}{c}\text { Não } \\
\text { atende }\end{array}$ & -1 & $\begin{array}{c}\text { Não } \\
\text { atende }\end{array}$ & -1 & Atende & 1 \\
\hline & & $\begin{array}{c}\text { Licença } \\
\text { Municipal }\end{array}$ & 5.2.c & Atende & 1 & Atende & 1 & $\begin{array}{c}\text { Não } \\
\text { atende }\end{array}$ & -1 & Atende & 1 \\
\hline & & $\begin{array}{c}\text { Licença } \\
\text { Ambiental }\end{array}$ & 5.2.c & Atende & 1 & Atende & 1 & Atende & 1 & Atende & 1 \\
\hline & \multirow{8}{*}{ } & Cerca Vegetal & $\begin{array}{l}\text { 5.2.a } \\
5.3 . \mathrm{d}\end{array}$ & $\begin{array}{c}\text { Não } \\
\text { atende }\end{array}$ & -1 & $\begin{array}{c}\text { Não } \\
\text { atende }\end{array}$ & -1 & $\begin{array}{c}\text { Não } \\
\text { atende }\end{array}$ & -1 & Atende & 1 \\
\hline & & $\begin{array}{c}\text { Aceitação } \\
\text { Popular }\end{array}$ & $\begin{array}{l}\text { 5.3. } \\
\text { 5.3.d }\end{array}$ & $\begin{array}{c}\text { Não } \\
\text { atende }\end{array}$ & -1 & $\begin{array}{l}\text { Atende } \\
\text { parcial }\end{array}$ & 0 & $\begin{array}{l}\text { Atende } \\
\text { parcial }\end{array}$ & 0 & Atende & 1 \\
\hline & & Isolamento & $\begin{array}{l}5.3 . \mathrm{a} \\
5.3 . \mathrm{b} \\
5.3 . \mathrm{d}\end{array}$ & Atende & 1 & Atende & 1 & Atende & 1 & Atende & 1 \\
\hline & & Sinalização & 5.3.c & Atende & 1 & Atende & 1 & Atende & 1 & Atende & 1 \\
\hline & & Acesso Interno & $\begin{array}{c}5.2 .1 \mathrm{c} \\
5.4\end{array}$ & Atende & 1 & $\begin{array}{c}\text { Não } \\
\text { atende }\end{array}$ & -1 & $\begin{array}{c}\text { Não } \\
\text { atende }\end{array}$ & -1 & $\begin{array}{c}\text { Não } \\
\text { atende }\end{array}$ & -1 \\
\hline & & Emissão de Pó & $\begin{array}{l}\text { 5.3.d } \\
7.1 .3\end{array}$ & $\begin{array}{c}\text { Não } \\
\text { atende }\end{array}$ & -1 & $\begin{array}{c}\text { Não } \\
\text { atende }\end{array}$ & -1 & $\begin{array}{c}\text { Não } \\
\text { atende }\end{array}$ & -1 & Atende & 1 \\
\hline & & $\begin{array}{c}\text { Recepção } \\
\text { (local) }\end{array}$ & 6.3 & $\begin{array}{c}\text { Não } \\
\text { atende }\end{array}$ & -1 & $\begin{array}{c}\text { Não } \\
\text { atende }\end{array}$ & -1 & $\begin{array}{c}\text { Não } \\
\text { atende }\end{array}$ & -1 & $\begin{array}{c}\text { Não } \\
\text { atende }\end{array}$ & -1 \\
\hline & & Triagem (local) & 6.3 & $\begin{array}{c}\text { Não } \\
\text { atende }\end{array}$ & -1 & $\begin{array}{c}\text { Não } \\
\text { atende }\end{array}$ & -1 & $\begin{array}{c}\text { Não } \\
\text { atende }\end{array}$ & -1 & $\begin{array}{c}\text { Não } \\
\text { atende }\end{array}$ & -1 \\
\hline \multicolumn{4}{|c|}{ Total Parcial } & & -4 & & -3 & & -7 & & 7 \\
\hline \multicolumn{4}{|c|}{ \% de Conformidade } & \multicolumn{2}{|c|}{$35,70 \%$} & \multicolumn{2}{|c|}{$39,27 \%$} & \multicolumn{2}{|c|}{$25,00 \%$} & \multicolumn{2}{|c|}{$\mathbf{7 5 , 0 0 \%}$} \\
\hline
\end{tabular}

Nota: *VA - valor atribuído conforme descrito na metodologia. 
No terreno da usina "A" o índice de contaminação do subsolo foi apontado como dificuldade ao crescimento da cerca vegetal. Nas usinas "B" e "C", a insuficiência decorre de pouco espaço físico e do plantio de espécie não natural, propícia à produção de madeira. Na usina " $D$ ", a diversidade de espécies e o porte da vegetação nativa foram apontados como barreira eficiente ao ruído e à poeira.

A presença de corpos hídricos foi constatada nas usinas (A, C e D). Somente na usina "D" a vegetação nativa foi mantida como dispositivo de preservação.

Nas usinas avaliadas, a implantação do núcleo de britagem apresenta sistema de pulverização de água para a redução das emissões de pó. Na usina "B" também se constatou o dispositivo na entrada dos veículos e na armazenagem do RCC. Na usina " $D$ " os aspersores estão distribuídos ao longo da via de acesso interno, não se evidenciando molhagem na armazenagem do RCC nem dos agregados reciclados.

Além da emissão de poeira e de ruído, a imagem negativa das usinas está associada ao histórico do terreno. Na usina "A" a extração clandestina de areia e a posterior disposição de resíduos urbanos que atraíram catadores fizeram desse terreno um ambiente de constante expropriação. Essa usina possui o maior número de vigias entre as empresas visitadas.

Nas usinas avaliadas, o local para recepção e triagem dos veículos com carga interrompe os trânsitos externo e interno. Nesse aspecto, o fluxo previsto em projeto e praticado nas usinas não permite a constatação da carga entregue. Não foi evidenciada a existência de armazenagem da matéria-prima por tipologia construtiva.

Todas as usinas visitadas obtiveram as licenças municipais, ambientais, de implantação e operação. Apesar disso, constatou-se não conformidade para adequação do local, hidrologia, área para vegetação e vias de acesso.

\section{Operação}

O Quadro 3 contém a avaliação das diretrizes relativas à operação das usinas de reciclagem de RCC quanto aos aspectos de recebimento, armazenagem, triagem, redução, máquinas e equipamentos.

Nas usinas avaliadas, a vistoria do RCC é visual e se dá pela parte superior do veículo, prática que não garante a natureza mineral do RCC. Como efeito, constata-se a redução das áreas de armazenagem e movimentação dos equipamentos. Na etapa da vistoria não existe rejeição de RCC.
A admissão e a triagem das usinas " $A$ " e "B" foram declaradas, pelo entrevistado, como em conformidade com a norma, isto em virtude da infrequência do recebimento de matéria-prima.

Nas usinas "C" e "D" é exigida a entrega do documento de Controle de Transporte de Resíduo (CTR). Quando não expedido pelo gerador, é emitido no escritório das usinas. Durante as visitas constatou-se divergência entre a guia CTR e a carga entregue, indicando a ausência de conformidade ao RCC entregue.

As usinas visitadas não utilizam prébeneficiamento, ausência que justifica a ineficiência e lentidão no processo de triagem, pois essa etapa concentra o maior número de operários. Nas usinas "B", "C" e "D" existem postos de triagem manual também após a britagem, onde somente deveria existir a triagem magnética. Nesse aspecto, a remoção dos aços do RCC foi avaliada como satisfatória em todas as usinas.

Quanto aos equipamentos das usinas, a pá carregadeira é a que provoca o maior número de interrupções durante a triagem, britagem e movimentação de cargas. A quantidade de pás é insuficiente para as atividades a realizar. Assim, as movimentações de insumos e produtos ficam rotineiramente comprometidas, e a justificativa para tanto recai sobre o custo de aquisição do equipamento.

O britador das usinas foi escolhido em função da dureza do RCC a reduzir. As usinas "A", "B" e "C" possuem britador de martelo recomendado para RCC de menor dureza, já na usina " $D$ " o britador de mandíbula também reduz pedra e concreto.

As usinas "A" e "D" apresentaram não conformidade com relação à presença de equipamentos destinados à confecção de préfabricados de concreto reciclado. Essa coexistência interfere na finalidade das usinas.

Ainda conforme a NBR 15114 (ABNT, 2004b), os operários devem ser treinados. $\mathrm{Na}$ usina " $\mathrm{A}$ " os cursos foram sobre primeiros socorros e combate a incêndio. De modo complementar são dadas palestras sobre redução da obesidade, noções de higiene pessoal e uso dos equipamentos de proteção individual.

$\mathrm{Na}$ usina "B" todos os funcionários receberam treinamento para combate a incêndio e primeiros socorros à época da implantação. Na usina "C" os operários foram treinados somente para primeiros socorros, fato reconhecido como desfavorável às atividades. Na usina " $D$ " somente os trabalhadores estáveis tinham treinamento para primeiros socorros e combate a incêndio. 
Quanto à operação de redução do RCC, na usina "C" ocorre durante 3 horas por dia, o equivalente a $37,5 \%$ da capacidade efetiva. As outras 5 horas se destinam a triagem, separação e empilhamento de RCC. Essa rotina permite produção contínua do britador e decorre da quantidade de pás carregadeiras. $\mathrm{Na}$ usina " $\mathrm{D}$ " a britagem frequentemente é superior a 8 horas/dia. Essa irregularidade nas usinas " $C$ " e " $D$ " conduziu à não conformidade, sobretudo na gestão dos resíduos.

\section{Matéria-prima, produto e resíduos}

No Quadro 4 tem-se a avaliação de conformidade da matéria-prima, produtos reciclados e resíduos gerados.

As práticas de canteiro de obra interferem nas usinas quando misturam substâncias inertes e reativas, perigosas e tóxicas. Nas usinas "A", "C" e " $D$ " se evidenciou a admissão de RCC independentemente do tipo de obra e do teor de contaminação, justificando-se essa prática como favorável à redução da disposição do RCC no meio urbano.

Quadro 3 - Avaliação das diretrizes - operação das usinas

\begin{tabular}{|c|c|c|c|c|c|c|c|c|c|c|c|}
\hline & \multirow[b]{2}{*}{$\begin{array}{l}\text { Referências } \\
\text { Normativas }\end{array}$} & \multirow[b]{2}{*}{$\begin{array}{l}\text { Diretrizes } \\
\text { Observadas }\end{array}$} & \multirow{2}{*}{$\begin{array}{c}\text { Item da } \\
\text { NBR } \\
\text { 15114 } \\
\text { (ABNT, } \\
\text { 2004) } \\
\end{array}$} & \multicolumn{2}{|c|}{ Usina A } & \multicolumn{2}{|c|}{ Usina B } & \multicolumn{2}{|c|}{ Usina C } & \multicolumn{2}{|c|}{ Usina D } \\
\hline & & & & Conceito & VA* & Conceito & VA* & Conceito & VA* & Conceito & VA* \\
\hline \multirow{18}{*}{ 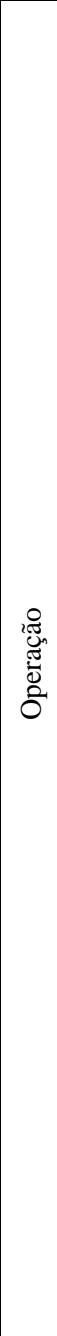 } & \multirow{3}{*}{ Admissão } & Vistoria & - & $\begin{array}{c}\text { Não } \\
\text { atende }\end{array}$ & -1 & $\begin{array}{l}\text { Atende } \\
\text { parcial }\end{array}$ & 0 & $\begin{array}{c}\text { Não } \\
\text { atende }\end{array}$ & -1 & $\begin{array}{c}\text { Não } \\
\text { atende }\end{array}$ & -1 \\
\hline & & $\underline{\text { Mediçãao }}$ & - & Atende & 1 & Atende & 1 & $\begin{array}{c}\text { Não } \\
\text { atende }\end{array}$ & -1 & $\begin{array}{c}\text { Não } \\
\text { atende }\end{array}$ & -1 \\
\hline & & CTR & $\begin{array}{c}3.1 .1 \\
7.1 .1 \\
\text { Anexo A }\end{array}$ & $\begin{array}{c}\text { Não } \\
\text { atende }\end{array}$ & -1 & $\begin{array}{c}\text { Não } \\
\text { atende }\end{array}$ & -1 & $\begin{array}{c}\text { Não } \\
\text { atende }\end{array}$ & -1 & $\begin{array}{c}\text { Não } \\
\text { atende }\end{array}$ & -1 \\
\hline & $\begin{array}{c}\text { Pré- } \\
\text { beneficiamento }\end{array}$ & Mecânico & - & $\begin{array}{c}\text { Não } \\
\text { atende }\end{array}$ & -1 & $\begin{array}{c}\text { Não } \\
\text { atende }\end{array}$ & -1 & $\begin{array}{c}\text { Não } \\
\text { atende }\end{array}$ & -1 & $\begin{array}{c}\text { Não } \\
\text { atende }\end{array}$ & -1 \\
\hline & \multirow{3}{*}{ Triagem } & Manual & - & Atende & 1 & Atende & 1 & $\begin{array}{l}\text { Atende } \\
\text { parcial }\end{array}$ & 0 & $\begin{array}{l}\text { Atende } \\
\text { parcial }\end{array}$ & 0 \\
\hline & & Mecânico & - & $\begin{array}{c}\text { Não } \\
\text { atende }\end{array}$ & -1 & $\begin{array}{c}\text { Não } \\
\text { atende }\end{array}$ & -1 & $\begin{array}{c}\text { Não } \\
\text { atende }\end{array}$ & -1 & $\begin{array}{c}\text { Não } \\
\text { atende }\end{array}$ & -1 \\
\hline & & Magnética & - & Atende & 1 & Atende & 1 & Atende & 1 & Atende & 1 \\
\hline & $\begin{array}{c}\text { Controle de } \\
\text { qualidade - antes } \\
\text { do beneficiamento }\end{array}$ & Tipo & 7.4 & $\begin{array}{c}\text { Não } \\
\text { atende }\end{array}$ & -1 & $\begin{array}{c}\text { Não } \\
\text { atende }\end{array}$ & -1 & $\begin{array}{c}\text { Não } \\
\text { atende }\end{array}$ & -1 & $\begin{array}{c}\text { Não } \\
\text { atende }\end{array}$ & -1 \\
\hline & \multirow{3}{*}{ Britador } & Tipo & - & Atende & 1 & Atende & 1 & Atende & 1 & Atende & 1 \\
\hline & & Produção & - & Atende & 1 & Atende & 1 & Atende & 1 & Atende & 1 \\
\hline & & Peneiras & - & Atende & 1 & Atende & 1 & Atende & 1 & Atende & 1 \\
\hline & \multirow{4}{*}{$\begin{array}{l}\text { Máquina e equipa } \\
\text { mento }\end{array}$} & Pá carregad. & - & $\begin{array}{c}\text { Não } \\
\text { atende }\end{array}$ & -1 & $\begin{array}{c}\text { Não } \\
\text { atende }\end{array}$ & -1 & $\begin{array}{c}\text { Não } \\
\text { atende }\end{array}$ & -1 & $\begin{array}{c}\text { Não } \\
\text { atende }\end{array}$ & -1 \\
\hline & & Caminhão poli & - & $\begin{array}{c}\text { Não } \\
\text { atende }\end{array}$ & -1 & Atende & 1 & Atende & 1 & Atende & 1 \\
\hline & & Mesa vibrat. & - & $\begin{array}{c}\text { Não } \\
\text { atende }\end{array}$ & -1 & Atende & 1 & Atende & 1 & Atende & 1 \\
\hline & & Betoneira & - & $\begin{array}{c}\text { Não } \\
\text { atende }\end{array}$ & -1 & Atende & 1 & Atende & 1 & Atende & 1 \\
\hline & \multirow[b]{2}{*}{ Treinamento } & Operação & 7.2 .1 & Atende & 1 & Atende & 1 & Atende & 1 & Atende & 1 \\
\hline & & Emergência & $\begin{array}{l}7.2 .2 \\
7.3 \\
\end{array}$ & Atende & 1 & Atende & 1 & Atende & 1 & Atende & 1 \\
\hline & $\begin{array}{c}\text { Controle de } \\
\text { qualidade - após } \\
\text { beneficiamento }\end{array}$ & Tipo & 7.4.1 & $\begin{array}{c}\text { Não } \\
\text { atende }\end{array}$ & -1 & $\begin{array}{c}\text { Não } \\
\text { atende }\end{array}$ & -1 & $\begin{array}{c}\text { Não } \\
\text { atende }\end{array}$ & -1 & $\begin{array}{c}\text { Não } \\
\text { atende }\end{array}$ & -1 \\
\hline \multicolumn{5}{|c|}{ Total Parcial } & -2 & & 5 & & -1 & & -1 \\
\hline \multicolumn{4}{|c|}{$\%$ de Conformidade } & \multicolumn{2}{|c|}{$44,48 \%$} & \multicolumn{2}{|c|}{$63,94 \%$} & \multicolumn{2}{|c|}{$47,26 \%$} & \multicolumn{2}{|c|}{$47,26 \%$} \\
\hline
\end{tabular}

Nota: *VA - valor conforme descrito na metodologia. 
Quadro 4 - Avaliação das diretrizes - Matéria-prima, produto e resíduos

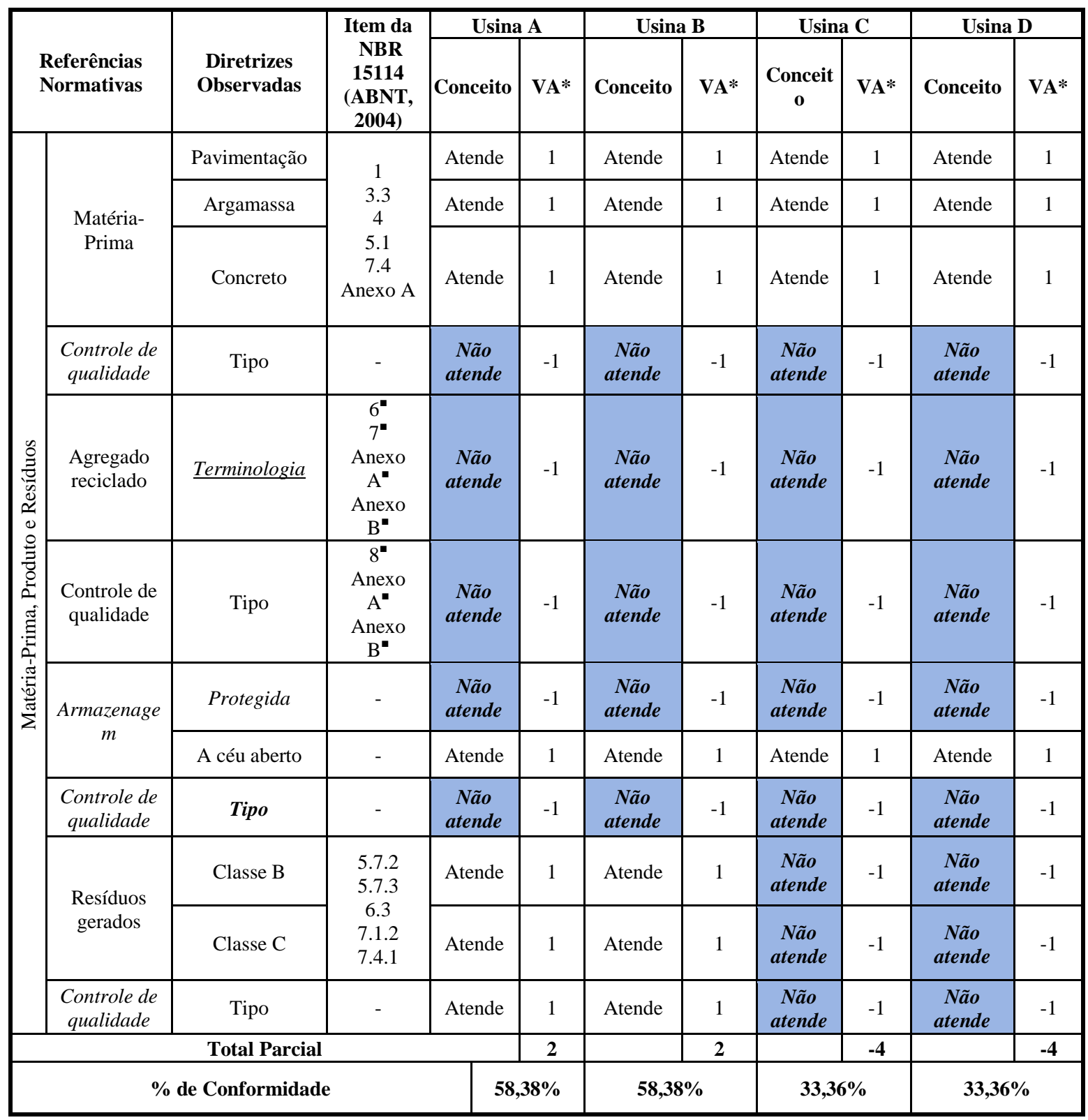

Nota: *VA - valor atribuído conforme descito na metodologia. ' 'item da NBR 15116 (ABNT, 2004C).

Quanto à terminologia do agregado reciclado, cada usina possui designação própria, desfavorecendo e dificultando o reconhecimento do produto reciclado. O Quadro 5 traz a identificação utilizada por cada unidade, seu emprego e destinação.

Na rotina de admissão do RCC, expedição dos produtos e resíduos triados, constatou-se inexistir pesagem, prática que não permite controle do agregado reciclado em relação aos resíduos expedidos.

\section{Fatores críticos para a produção de agregados reciclados}

A partir da avaliação das quatro usinas de reciclagem da região Nordeste do Brasil, foi possível identificar fatores críticos que influenciam positiva ou negativamente para a produção de agregados reciclados. 
Quadro 5 - Terminologia utilizada na entrega do agregado reciclado

\begin{tabular}{|c|c|c|c|c|c|c|c|c|c|c|c|}
\hline \multirow{3}{*}{$\begin{array}{c}\text { Abertura } \\
\text { da } \\
\text { Peneira } \\
(\mathbf{m m})\end{array}$} & \multicolumn{11}{|c|}{ Terminologia - Aplicação (In Natura e Subprodutos) } \\
\hline & \multicolumn{2}{|c|}{ Usina"A" } & \multicolumn{3}{|c|}{ Usina "B" } & \multicolumn{3}{|c|}{ Usina "C" } & \multicolumn{3}{|c|}{ Usina "D" } \\
\hline & ARM & & ARC & $\mathbf{A R M}^{1}$ & & $\mathbf{A R C}^{2}$ & ARM & & $\mathbf{A R} \mathbf{P}^{3}$ & ARM & \\
\hline$>25,4$ & $\begin{array}{c}\text { Agregad } \\
\text { o } \\
\text { Reciclad } \\
\text { o }\end{array}$ & & Brita 02 & Rachão & & Rachão & & & & & 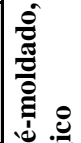 \\
\hline $\begin{array}{c}9,5< \\
\emptyset<25,4\end{array}$ & $\begin{array}{c}\text { Pedra } 1 \\
\text { Reciclad } \\
\text { a }\end{array}$ & $\frac{8}{30}$ & Brita 01 & Pedra 1 & 胥 & Brita 19 & $\begin{array}{l}\text { Bica } \\
\text { Corrida }\end{array}$ & ્ָ⿹ & $\begin{array}{c}\text { Brita } \\
25\end{array}$ & & 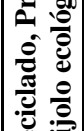 \\
\hline $\begin{array}{c}4,8<\varnothing \\
<9,5\end{array}$ & $\begin{array}{c}\text { Pedrisco } \\
\text { Reciclad } \\
\text { o }\end{array}$ & 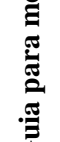 & Brita 00 & Pedrisco & 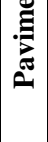 & Cascalhinho & & تี & $\begin{array}{c}\text { Brita } \\
12,5\end{array}$ & $\begin{array}{l}\text { Solo } \\
\text { Brita }\end{array}$ & 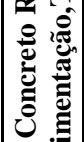 \\
\hline$<4,8$ & $\begin{array}{c}\text { Areia } \\
\text { Reciclad } \\
\text { a }\end{array}$ & 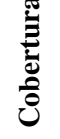 & $\begin{array}{l}\text { Pós de } \\
\text { Pedra }\end{array}$ & $\begin{array}{l}\text { Bica } \\
\text { Corrida }\end{array}$ & & Pó de Brita & $\begin{array}{l}\text { Bica } \\
\text { Fixa }\end{array}$ & & & & 苞 \\
\hline
\end{tabular}

Nota: Legenda:

${ }^{1}$ Agregado Reciclado misto com menos de $90 \%$ de RCC de concreto;

${ }^{2}$ Agregado Reciclado de Concreto com mais de $90 \%$ de RCC de concreto;

${ }^{3}$ Agregado Reciclado de Pedra de pavimentação.

\section{Projeto e implantação das usinas}

As usinas devem ter por objetivo a oferta de produtos reciclados que satisfaçam requisitos técnicos de empregabilidade e sustentabilidade (WASTE..., 2005). A concepção do projeto e a implantação das usinas avaliadas apresentam fragilidades na admissão, nas áreas de circulação de veículos, nas áreas de destinação do RCC e do agregado reciclado.

A implantação de usinas em terrenos exíguos não satisfaz as necessidades da recepção, inspeção e triagem, desfavorecendo a armazenagem por tipologia. Em três das instalações avaliadas os terrenos ditam o ritmo acelerado da redução e interferem negativamente na produção do agregado reciclado.

A localização e o terreno das usinas se apresentaram como essenciais para as iniciativas pública e privada. Na iniciativa pública a não aquisição de terras se sobrepõe a requisitos técnicos, que afetam a produção diária e resultam em imagem negativa do empreendimento e do produto, indicando redução da perspectiva produtiva. Nesse aspecto a iniciativa privada visa à produção como parâmetro determinante, evidenciando-se o propósito de permanência da usina no local, mesmo com expansão das cidades.
$\mathrm{O}$ terreno da usina deve permitir atender às necessidades sazonais da construção civil.

O terreno das usinas deve propiciar a reserva de área de vegetação nativa, favorecendo a redução das emissões de pó e ruído (MELO, 2011). A presença de corpos hídricos não elimina a possibilidade de contaminação do subsolo por lixiviação do RCC armazenado.

Os projetos analisados e os croquis construídos sugerem que o fluxo de equipamentos e veículos das usinas está comprometido pela armazenagem. $\mathrm{O}$ projeto deve ter um arranjo físico que impeça o fluxo cruzado entre veículo e equipamentos (MUTHER, 1978; MOREIRA, 2001).

A localização e o terreno das usinas interferem negativamente na operação e no controle da matéria-prima e no produto final. O Quadro 6 resume as interferências evidenciadas.

As diretrizes adotadas pela NBR 15114 (ABNT, 2004b) conduzem à contaminação do RCC fora e dentro das usinas, na medida em que estabelecem que os solos são RCC beneficiável nessas áreas. Outra contribuição negativa da norma está em desobrigar o uso de equipamentos que melhoram os requisitos técnicos do agregado reciclado. 


\section{Operação das usinas}

O solo tratado e separado por tipo mineral apresenta condição favorável ao reemprego em obras de aterro, pavimentação, paisagismo ou aterros sanitários, podendo, inclusive, adequar-se como matéria-prima à indústria dos materiais de construção, conforme Gilpin Junior, Menzie e Hyun (2004). Por outro lado, atende ao princípio do reúso, como discutido por Hendriks (2004) e Car et al. (2008).

O controle dos insumos e dos produtos das usinas em volume impede a formulação de indicadores produtivos, pois existe diferença de massa específica entre eles. Desse modo não se conhece a taxa de aproveitamento do RCC em relação ao produto reciclado, tampouco qual o teor de contaminação do RCC. Assim, as usinas avaliadas contribuem para aplicações pouco nobres do agregado reciclado.

A triagem manual das usinas avaliadas é ineficaz na redução das contaminações. A triagem magnética feita por ímã apresenta adequação, mas se observou que parte das armaduras presentes no RCC é removida somente na triagem manual.

Quanto ao núcleo de britagem das usinas, a escolha do equipamento decorre da dureza do RCC, sendo possível afirmar ter havido desconsideração quanto ao tipo de agregado reciclado a produzir, sua granulometria e a variação da dureza do RCC. Essa despreocupação indica que o projeto das usinas avaliadas está dissociado das perspectivas de crescimento das cidades e das demolições de estruturas de concreto. O Quadro 7 resume os fatores evidenciados na operação.

\section{Quadro 6 - Fatores críticos para a produção do agregado reciclado - projeto e implantação}

\begin{tabular}{|c|c|c|}
\hline \multirow{4}{*}{$\begin{array}{c}\text { Projeto } \\
\text { Implantação }\end{array}$} & $\begin{array}{c}\text { Área disponibilizada para } \\
\text { implantação }\end{array}$ & $\begin{array}{c}\text { Acesso inadequado, ausência de áreas para } \\
\text { vegetação com copas altas, médias e baixas, } \\
\text { hidrologia não preservada. }\end{array}$ \\
\cline { 2 - 3 } & Localização - Impactos na vizinhança & $\begin{array}{c}\text { Emissões de ruído, pó e vibração, acréscimo na } \\
\text { movimentação de veículos. }\end{array}$ \\
\cline { 2 - 3 } & Impactos na produção & $\begin{array}{c}\text { Áreas exíguas de recepção, triagem, vistoria, fluxo } \\
\text { cruzado de veículos, vias estreitas para } \\
\text { movimentação dos veículos, sinalização e } \\
\text { isolamento das vias inadequado, procedimentos } \\
\text { operacionais dissociados que não garantem } \\
\text { requisitos técnicos aos produtos reciclados. }\end{array}$ \\
\hline
\end{tabular}

\section{Quadro 7 - Fatores críticos para a produção do agregado reciclado - operação}

\begin{tabular}{|c|c|}
\hline $\begin{array}{c}\text { Máquinas e } \\
\text { equipamentos }\end{array}$ & $\begin{array}{c}\text { Quantidade inadequada de pá carregadeira para a produção, fluxo intenso em área } \\
\text { exígua, britador único escolhido pela dureza do RCC, sem evidência de pré- } \\
\text { beneficiamento e equipamentos de lavagem. }\end{array}$ \\
\hline $\begin{array}{c}\text { Procedimentos } \\
\text { operacionais } \\
\text { adotados }\end{array}$ & $\begin{array}{c}\text { Admissão de RCC independente do teor de contaminação, britagem descontínua do } \\
\text { RCC, limitação de atividades que impactam na vizinhança (poeira e ruído), acentuada } \\
\text { geração de resíduos, triagem manual lenta e pouco eficaz, ausência de indicadores de } \\
\text { produção em massa. }\end{array}$ \\
\hline $\begin{array}{c}\text { Treinamento e } \\
\text { mão de obra }\end{array}$ & $\begin{array}{c}\text { Diversidade de grau de instrução, rotatividade nos postos de menor qualificação, } \\
\text { treinamento para combate a incêndio e primeiros socorros. }\end{array}$ \\
\hline
\end{tabular}

Nos países onde a produção de agregado reciclado se destina à aplicação dentro do ciclo de vida do material, qualquer etapa que interfira na composição mineral do RCC é avaliada (WASTE..., 2005). Os procedimentos operacionais permitem rejeito do RCC antes do acesso para armazenagem (por tipologia) e antes da redução. Os procedimentos operacionais fornecem às usinas parâmetros produtivos constatados por ensaios do produto reciclado (WASTE..., 2005).

\section{Matéria-prima e resíduos}

A matéria-prima das usinas avaliadas inviabiliza a produção de agregados reciclados com requisitos técnicos dentro do ciclo de vida do material. Essa inadequação prejudica a inserção do agregado reciclado no mercado consumidor.

A ausência de terminologia normalizada para o agregado reciclado gera desconfiança na linha do produto. Por outro lado, não fixa os índices físicos do agregado reciclado como material de 
construção, sugerindo-se, assim, que se estudem a granulometria, a massa específica e a absorção de água como requisitos técnicos regionais.

Por certo, o fator crítico do agregado reciclado ainda será a variabilidade mineral e o desconhecimento sobre sua reatividade quando empregado. No entanto, a avaliação das usinas indicou existir tendência local para a composição mineral. Esse tipo de interferência sugere que são reduzidas as chances de produção de agregado reciclado com mineralogia homogênea em regiões distintas do país, ao contrário dos municípios próximos, onde existe possibilidade de comercialização de linha de produtos semelhantes.

Quanto às diretrizes de armazenagem da matériaprima e do produto em usinas, sem distinção por tipologia, é possível afirmar que há incerteza por parte do consumidor quanto ao desempenho do produto reciclado.

O resíduo gerado pelas usinas avaliadas indica GRCC insatisfatória. Quando a quantidade é suficiente para comercialização, sugere que as usinas respondem socialmente por uma atividade diferente da proposta em norma. Quando os resíduos diminuem o ritmo da triagem, interferem na produção efetiva do britador. O Quadro 8 resume os fatores críticos evidenciados na matériaprima, resíduos e produto.

\section{Proposições à produção do agregado reciclado}

Com base no estudo nas quatro usinas de reciclagem em operação da região Nordeste do Brasil até o período de 2010, foi possível estabelecer proposições para a produção do agregado reciclado, que podem ser adotadas por outras usinas de reciclagem brasileiras, desde que observadas suas especificidades e contexto de implantação. As proposições referem-se a:
(a) projeto para implantação das usinas;
(b) procedimentos operacionais das usinas;
(c) matéria-prima; e
(d) produção dos agregados reciclados.

O projeto para implantação da usina de reciclagem de RCC que tenha por objetivo atender ao mercado consumidor com uma linha de agregado reciclado de menor variabilidade mineral e empregabilidade deve ter como elementos de concepção:

(a) área para recepção de RCC que permita movimentação, derrubada e carregamento de modo a existir constatação do teor de contaminação mineral recebido;

(b) área de estocagem de RCC por tipologia construtiva;

(c) área de estocagem por linha de produto reciclado separadamente;

(d) previsibilidade das vias de acesso para o fluxo de veículos e equipamentos em faixas distintas;

(e) previsibilidade de cerca vegetal nativa com alturas diferenciadas como dispositivo de redução das emissões de poeira e ruído; e

(f) implantação em áreas adequadas à instalação industrial com necessidades semelhantes à extração mineral (dimensões, relevo, acessos, ausência de corpos hídricos). Quanto à iniciativa pública, cabe considerar quais requisitos técnicos justificam a aquisição de terras adequadas.

\section{Quadro 8 - Fatores críticos para a produção do agregado reciclado - matéria-prima, resíduos e produto}

\begin{tabular}{|c|c|c|}
\hline $\begin{array}{c}\text { Matéria- } \\
\text { prima }\end{array}$ & $\begin{array}{c}\text { Admissão sem segregação satisfatória, constatação visual do RCC pela superfície do } \\
\text { veículo, admissão de RCC diferente da classe A, admissão de material de escavação e } \\
\text { movimentação de solo, divergência entre a guia de controle de transporte e RCC do } \\
\text { veículo, rotina de admissão de RCC por volume sem controle em massa. }\end{array}$ \\
\hline Produto & $\begin{array}{c}\text { Terminologia diferente por usina, ausência de padrão granulométrico, significativo teor de } \\
\text { contaminação, composição mineral da linha de produto com tendência regional, linha de } \\
\text { produto destinada à pavimentação, ausência de controle de qualidade do produto final por } \\
\text { amostra representativa, rotina de expedição do RCC por volume e não por massa. }\end{array}$ \\
\hline Resíduos & $\begin{array}{c}\text { Comercialização dos resíduos da classe B, rotina de expedição do resíduo por volume, } \\
\text { presença de resíduos domésticos urbanos, significativa presença de resíduos em relação ao } \\
\text { volume de RCC, práticas intencionais para ocultar RCC diferente da classe A através da } \\
\text { disposição conveniente do RCC no veículo de transporte. }\end{array}$ \\
\hline
\end{tabular}

112 Melo, A. V. S.; Ferreira, E. de A. M.; Costa, D. B. 
Com relação aos procedimentos operacionais das usinas de reciclagem de RCC avaliadas, é possível afirmar que o agregado reciclado tenha menor heterogeneidade se:

(a) todo RCC não triado for rejeitado na recepção;

(b) a usina adotar procedimento de notificação ao gerador todas as vezes que houver presença de contaminações excessivas;

(c) a usina adotar estratégias que reduzam a interrupção das atividades realizadas por máquinas e equipamentos, ou dimensionar a aquisição de maquinário à produção;

(d) a usina adotar dispositivos de controle de qualidade para as etapas produtivas, incluindo-se o descarte do RCC como favorável à produção. Como controle da variabilidade mineral, deve haver armazenagem do produto reciclado por tipologia; e

(e) a usina adotar um programa de treinamento de pessoal específico para a produção do agregado reciclado.

No que diz respeito à matéria-prima, a rejeição dos solos nas usinas contribuirá significativamente na eliminação de contaminações e finos. O controle no acesso dos insumos em massa determinará o registro e acompanhamento da linha dos produtos a comercializar. O controle do produto e dos resíduos em massa deve indicar os pontos críticos e as interferências negativas a corrigir.

Para a produção de agregado reciclado que atenda a requisitos técnicos de substituição aos agregados naturais, é importante que as diretrizes brasileiras, normas regulamentadoras e legislações apontem para:

(a) a inibição da geração do RCC como dispositivo que auxilie na segregação. Outros dispositivos podem ser utilizados desde que se atribuam ao gerador transgressor todas as responsabilidades econômicas e legais de suas práticas;

(b) a publicação de dispositivos que indiquem requisitos técnicos de aceitabilidade para o agregado reciclado;

(c) a publicação de dispositivos complementares à NBR 15114 (ABNT, 2004b) que regulem critérios de operação das usinas visando respeitar requisitos técnicos do agregado reciclado;

(d) a publicação de dispositivos que regulem as condições de instalação e operação de usinas com plantas móveis em canteiros de obra com demolição; e

(e) classificação do RCC, de modo a não destinar às usinas de reciclagem de RCC os solos, os materiais de escavação e os resíduos das obras de pavimentação, a exceção das pedras naturais.

\section{Conclusão}

A principal contribuição deste trabalho foi identificar os fatores críticos e proposições de melhorias para produção do agregado reciclado nas usinas de reciclagem avaliadas. Os fatores críticos e as proposições referem-se a:

(a) projeto para implantação das usinas;

(b) procedimentos operacionais das usinas;

(c) matéria-prima; e

(d) produção dos agregados reciclados.

As proposições de melhorias identificadas podem servir como base para a adequação do conjunto das normas NBR 15112 (ABNT, 2004a) a 15116 (ABNT, 2004c), com o objetivo de fornecer ao produto reciclado maior empregabilidade na indústria de materiais de construção. Ainda foi possível constatar a ausência de normas técnicas publicadas para instalação e operação de usinas de reciclagem de RCC móveis. Cabe destacar que as proposições de melhorias podem ser adotadas por outras usinas de reciclagem brasileiras, desde que observadas suas especificidades e contexto de implantação.

A partir das análises também é possível afirmar que a NBR 15114 (ABNT, 2004b) não contempla requisitos de controle e qualidade da produção do agregado reciclado que conduzam à redução da variabilidade do RCC. Dessa forma, favorece a produção de agregado reciclado destinado à pavimentação, ratificando a limitada atenção aos requisitos técnicos.

Outra contribuição deste trabalho resultou na avaliação das usinas de reciclagem de RCC com foco na norma brasileira e nas boas práticas para a produção do agregado reciclado. As quatro usinas de reciclagem de RCC da região Nordeste avaliadas não apresentaram conformidade a todas as condições requeridas pela NBR 15114 (ABNT, 2004b). Nos requisitos de implantação e projeto, a conformidade oscila entre $25 \%$ e $75 \%$, atribuindose a menor conformidade ao tamanho da área utilizada e à proximidade com zona residencial.

Nos requisitos de operação, as usinas avaliadas apresentaram variação entre $44,48 \%$ e $63,94 \%$. Nesse caso a menor conformidade decorre da presença de equipamentos para fabricação de artefatos de concreto. Com relação às usinas " $\mathrm{B}$, "C" e "D", a não conformidade se deve às etapas de admissão e triagem, uma vez que suas atividades se subordinam às áreas utilizadas. 
Em relação à matéria-prima, ao produto e aos resíduos gerados, a conformidade foi de 58,38\%, confirmando que as quatro usinas avaliadas, na época desta pesquisa, produziam agregados reciclados que não atendiam aos requisitos técnicos.

A presença de RCC de classe diferente que " $A$ " nas usinas avaliadas indica que esses empreendimentos são percebidos como destinação dos RCC. Os requisitos técnicos destinados à produção de agregado reciclado, visando à empregabilidade e à pureza mineral não foram constatados como objetivo das quatro usinas avaliadas no Nordeste.

Outros estudos devem ser desenvolvidos visando à empregabilidade e à pureza mineral do agregado reciclado.

\section{Referências}

ALMEIDA, S. L.; CHAVES, A. P. Aproveitamento de Rejeitos de Pedreiras de Santo Antônio de Pádua - RJ. 2002. 69 p. (Série Rochas e Minerais Industriais). Disponível em: <http://www.cetem.gov.br/publicacao/series_srmi/ srmi-06.pdf>. Acesso em: 12 ago. 2013.

ÂNGULO, S. C. et al. Processamento de Resíduos de Construção e Demolição em Usinas de Reciclagem Europeias. In: ENCONTRO NACIONAL DE APROVEITAMENTO DE RESÍDUO NA CONSTRUÇÃO, Feira de Santana, 2009. Anais... Feira de Santana: ANTAC, 2009.

ASSOCIAÇÃO BRASILEIRA DE NORMAS TÉCNICAS. NBR 15114: resíduos sólidos da construção civil: diretrizes para projeto, implantação e operação. Rio de Janeiro, 2004b. 7 p. ASSOCIAÇÃO BRASILEIRA DE NORMAS TÉCNICAS. NBR 15112: resíduos da construção civil e resíduos volumosos: áreas de transbordo e triagem: diretrizes para projeto, implantação e operação. Rio de Janeiro, 2004a. 7 p.

\section{ASSOCIAÇÃO BRASILEIRA DE NORMAS}

TÉCNICAS. NBR 15116: agregados reciclados de resíduos sólidos da construção civil: utilização em pavimentação e preparo de concreto sem função estrutural: requisitos. Rio de Janeiro, 2004c. 12 p.

BALÁZS, G. L.; KAUSAY, T.; SIMON, T. K. Technical Guideline For the Production and Utilisation of Concrete Out of Recycled Aggregates in Hungary. In: ANNUAL JOURNAL OF THE HUNGARIAN GROUP OF FIB, 9., 2008. Proceedings... Budapest, 2008.
BREWER, G.; MOONEY, J. A Best Policy For Recycling and Reuse in Building. In:

INSTITUTION OF CIVIL ENGINEERSENGINEERING SUSTAINABILITY, 161., Newcastle, 2008. Proceedings... Newcastle, 2008.

CAR, M. et al. Recycling of Construction \& Demolition Waste in Malta: strategy for shartterm implementation. Malta: Ministry for rural affairs and the environment of Republic of Malta, 2008.

CUNHA, N. A. Resíduos da Construção Civil Análise de Usinas de Reciclagem. 176 f. Campinas, 2007. Dissertação (Mestrado em Engenharia Civil) - Escola de Engenharia, Universidade Estadual de Campinas, Campinas, 2007.

DUARTE, P.; LIMA, V. L. Beneficiamento do Resíduo de Construção. In: Congresso de Pesquisa e Inovação da Rede Norte Nordeste de Educação Tecnológica, 1., João Pessoa, 2007. Anais... João Pessoa, 2007.

GILPIN JUNIOR, R.; MENZIE, D. W.; HYUN, H. Recycling of Construction Debris as Aggregate in the Mid-Atlantic Region, USA. Resources

Conservation and Recycling, v. 42, n. 3, p. 275 294, 2004.

HENDRIKS, C. A New Vision on the Building Cycle. Amsterdam: AEneas Technical Publishers, 2004. v. 1.

JADOVSKI, I. Diretrizes Técnicas e Econômicas Para Usinas de Reciclagem de Resíduos de Construção e Demolição. 180 f. Porto Alegre, 2005. Dissertação (Mestrado Profissionalizante em Engenharia) - Escola de engenharia, Universidade Federal do Rio Grande do Sul, Porto Alegre, 2005.

KASAI, Y. Guidelines and the Present State of the Reuse of Demolished Concrete in Japan. In: INTERNATIONAL RILEM SYMPOSIUM, 3., 1994. Proceedings... 1994.

KAWANO, H. The State of Using By-Products in Concrete in Japan and Outline of JIS/TR on Recycled Concrete Using Recycled Aggregate. In: FIB CONGRESS ON RECYCLING, 1., Osaka, 2003. Proceedings... Osaka, 2003.

KIBERT, C. J. Concrete/Masoury Recycling Progress in the USA. In: INTERNATIONAL RILEM SYMPOSIUM, 3., Garston, 1994. Proceedings... Garston, 1994. 
LANZELLOTTI, R. F.; TOREM, M. L.; LUZ, A. B. Desenvolvimento de Fluxograma de Beneficiamento Mineral Para Resíduos Sólidos da Construção Civil. In: ENCONTRO NACIONAL DE TRATAMENTO DE MINÉRIOS E MINERALOGIA EXTRATIVA, 20., Florianópolis, 2004. Anais... Florianópolis, 2004. v. 2.

LÓPEZ, G. Gestión de los Resíduos de Construcción y Demolición (RCD) en la Comunidad de Madrid (España). In: Seminário Iberoamericano de Ingenieria de Resíduos, 3., João Pessoa, 2010. Anais... João Pessoa, 2010.

MANZINI, E.; VEZZOLI, C. O Desenvolvimento de Produtos Sustentáveis. São Paulo: EDUSP, 2008. v. 1.

MELO, A. V. S. Diretrizes Para a Produção de Agregado Reciclado em Usinas de Reciclagem de Resíduos da Construção Civil. 232 f. Salvador, 2011. Dissertação ( Mestrado em engenharia Ambiental Urbana) - Esola Politécnica, Universidade Federal da Bahia, Salvador, 2011.

MIRANDA, L. F.; ANGULO, S. C.; CARELI, É. D. A Reciclagem de Resíduos de Construção e Demolição no Brasil: 1986-2008. Ambiente Construído, Porto Alegre, v. 9, n. 1, p. 57-71, jan./mar. 2009.
MOREIRA, D. A. Administração da Produção e Operações. São Paulo: Pioneira, 2001.

MUTHER, R. Planejamento do Layout: sistema SLP. São Paulo: Edgard Blucher, 1978.

NUNES, K. R. Avaliação de Investimentos e Desempenho de Centrais de Reciclagem Para Resíduos Sólidos de Construção e Demolição. Rio de Janeiro: IBAM, 2004.

SHIMA, H. et al. An advanced Concrete Recycling Technology and Its Applicability Assessment Through Input-output Analysis. Journal of Advanced Concrete Technology, v. 3, n. 3, p. 53-66, 2005.

\section{WASTE \& RESOURCES ACTION}

PROGRAMME. Quality Protocol For the Production of Aggregates From Inert Waste. Hihgways Agency. Banbury, 2005. Disponível em: <http://www2.wrap.org.uk/downloads/0083_Quali ty_Protocol_A4.f4d71fb0.87.pdf>. Acesso em: 04 set. 2013.

YOSHIDA, F. The Cyclical Economy of Japan. Sapporo: HUSCAP, 2007.

Adriana Virgínia Santana Melo

Escola Técnica Federal de Sergipe | Instituto Federal de Sergipe | Av. Eng Gentil TAvares da Motta, 1166, Getúlio Vargas | Aracaju - SE Brasil | CEP 49055-260 | Tel.: (79) 3711-3100 Ramal 3219 | E-mail: adriana.melo@ifs.edu.br

Emerson de Andrade Marques Ferreira

Departamento de Construções e Estruturas, Escola Politécnica | Universidade Federal da Bahia | Rua Aristides Novis, 2, Federação | Salvador - BA - Brasil | CEP 40210-630 | Tel.: (71) 3283-9462 | E-mail: emerson@ufba.br

Dayana Bastos Costa

Departamento de Construções e Estruturas, Escola Politécnica | Universidade Federal da Bahia | Tel.: (71) 3283-9131 |

E-mail: dayanabcosta@ufba.br

Revista Ambiente Construído

Associação Nacional de Tecnologia do Ambiente Construído

Av. Osvaldo Aranha, $99-3^{\circ}$ andar, Centro

Porto Alegre - RS - Brasil

CEP $90035-190$

Telefone: +55 (51) 3308-4084

Fax: +55 (51) 3308-4054

www.seer.ufrgs.br/ambienteconstruido

E-mail: ambienteconstruido@ufrgs.br 